\title{
"SYNTHESIZING PROTEINS": AN EDUCATIONAL TOOL IN THE SIGHT OF
}

SCIENCE TEACHERS

J.C.Q.Carvalho; T.H.G. Oliveira; N.R.S. Bossolan; M.R.G. Oliveira; L.M. Beltramini

Centro de Biotecnologia Molecular Estrutural (CBME/CEPID/FAPESP)

Instituto de Física de São Carlos - USP, São Carlos, SP

e-mail: jcqcarvalho@ursa.ifsc.usp.br

In the current paradigm of science education, the student acquires an active position in the teaching -learning process, which is mediated by the teacher, whose continued teacher education must supply subsidies to the didactic transposition of new educational resources. The CBME in partnership with the Center of Scientific and Cultural Dissemination (CDCC) developed a board game that represents an outline of an animal cell and simulates the protein synthesis through the dynamics of several actions and component acquisition mediated by cards. To improve this didactic tool, the game was applied and evaluated during two courses of teachers' education in Molecular Biology and Biotechnology offered in 2006 by CBME: one in partnership with the Educational District of Sertãozinho (DE-SP) and the other promoted by the UFRN, in Natal (RN). The majority of the teachers of both groups considered the game applicable in classroom environment. Moreover, $59 \%$ of the Sertãozinho teachers' group and $25 \%$ of the Natal teachers' group had detected the following needs: a) more evident rules; $b$ ) time of game needs to be compatible with the classes' duration; c) restriction of the amount of players. Considering the pointed critics we inferred that the game already demonstrates a great educational potential, although it needs modifications for a better adaptation to the school reality. 